\title{
Analisis Pengaruh Corporate Governance dan Kualitas Audit terhadap Integritas Laporan Keuangan pada Perusahaan Manufaktur Sub Sektor Otomotif dan Komponen yang Terdaftar di Bursa Efek Indonesia Periode 2012-2017 (Analyzing the Effect of Corporate Governance and Audit Quality on the Integrity of Financial Statements in Manufacturing Companies of the Automotive and Component Sub-Sectors Listed on the Indonesia Stock Exchange for the Period 2012-2017)
}

Ambar Purwantiningsih ${ }^{1 *}$, Desy Anggaeni ${ }^{2}$

Fakultas Ekonomi dan Bisnis, Universitas Budi Luhur, Jakarta Selatan ${ }^{1,2}$

ambarpurwantiningsih9889@gmail.com ${ }^{1 *}$,desy.anggraeni@budiluhur.ac.id ${ }^{2}$

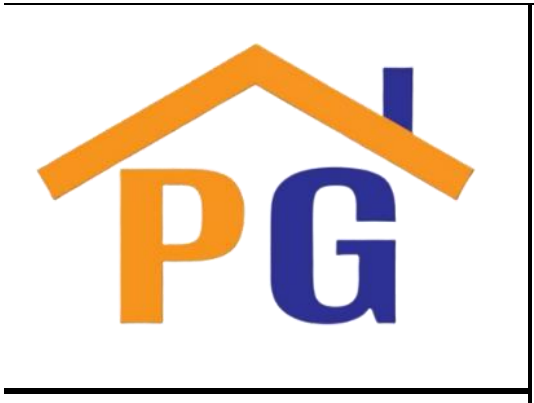

Riwayat Artikel

Diterima pada 20 Oktober 2020

Direvisi pada 1 April 2021

Disetujui pada 21 Juni 2021

\begin{abstract}
Purpose: The integrity of financial statements is the correctness of the information contained in financial statements that describe the actual condition of the company. This study examined the influence of Corporate Governance, which was proxied by Institutional Ownership, Managerial Ownership, Independent Commissioners, Audit Committees and the effect of Audit Quality on the Integrity of Financial Statements.
\end{abstract}

Research methodology: The population in this study were 13 Manufacturing and Automotive Sub Sector Manufacturing companies listed on the Indonesia Stock Exchange (IDX) for the 2012-2017 period. The sample selection technique used was purposive sampling and obtained six companies that met the researcher's criteria. The data analysis method used in this study is multiple linear regression analysis using SPSS version 25.0 for windows.

Results: The results show that institutional ownership, managerial ownership, independent commissioners, and audit quality have a positive and significant effect on the integrity of financial statements, while the audit committee has no effect on the integrity of financial statements.

Keywords: Institutional Ownership, Managerial Ownership, Independent Commissioners, Audit Committee, Integrity of Financial Statements

How to cite: Purwantiningsih, A.,\& Anggraeni. (2021). Analisis Pengaruh Corporate Governance dan Kualitas Audit terhadap Integritas Laporan Keuangan pada Perusahaan Manufaktur Sub Sektor Otomotif dan Komponen yang Terdaftar di Bursa Efek Indonesia Periode 2012-2017. Studi Akuntansi, Keuangan, dan Manajemen, 1(1), 33-43.

\section{Pendahuluan}

Indonesia merupakan negara berkembang yang di dalamnya terdapat banyak perusahaan, perusahaan tersebut terdiri dari perusahaan kecil hingga besar. Dikutip dari https://finance.detik.com (10/04/2019), Badan Pusat Statistik (BPS) telah melakukan sensus ekonomi 2016. Dari hasil sensus, jumlah perusahaan di Indonesia tercatat ada sebanyak 26,7 juta. Angka ini meningkat dibanding hasil sensus 
ekonomi 2006 yang sebanyak 22,7 juta perusahaan. Dari jumlah tersebut terdapat 555 perusahaan yang sudah go public yang tercantum di Bursa Efek Indonesia (BEI) (www.sahamok.com : 10/04/2019). Perusahaan go public menerbitkan saham-saham untuk diperjual-belikan kepada seluruh masyarakat sebagai cara untuk menambah atau memperoleh tambahan modal, sedangkan masyarakat yang membeli saham tersebut sebagai bentuk kepemilikan terhadap perusahaan tersebut, semakin banyak saham yang dibeli maka semakin besar juga presentase kepemilikannya terhadap perusahaan tersebut. Masyarakat yang membeli saham disuatu perushaan dinamakan sebagai investor.

Perusahaan go public yang tercantum di Bursa Efek Indonesia (BEI) setiap tahunnya menerbitkan laporan keuangan tahunan yang sudah diaudit (www.idx.com:10/04/2019). Laporan keuangan merupakan Laporan hasil dari informasi-informasi ekonomi perusahaan yang berjalan selama periode akuntansi. Laporan keuangan perusahaan sangat berguna untuk menentukan langkah pihak internal mengambil strategi terbaiknya agar mencapai target tahunan, dan juga berguna untuk pihak investor yang ingin berinvestasi pada perusahaan tersebut. Kebenaran informasi yang dicantumkan pihak internal perusahaan sangat penting, sebab jika terjadi kesalahan akan mengakibatkan informasi yang terkandung pada laporan keuangan tersebut tidak benar, hal ini akan berkakibat fatal, karena yang menyebabkan manajer salah mengambil keputusan untuk strategi perusahaan selanjutnya, dan juga pihak eksternal yang salah untuk memprediksi tempat berinvestasi. Kesalahan tersebut bisa dan tidak disengaja akibat kepentingan sebelah pihak yang menyebabkan laporan keuangan tidak berintegritas. Dalam keadaan yang sebenarnya, tidak semua berlaku secara teori, tidak semua berjalan secara jujur, yang mengakibatkan Laporan Keuangan Perusahaan tidak berintegritas demi kepentingan satu pihak maupun kelompok, dan merugikan beberapa pihak, seperti kesalahan informasi yang didapat oleh investor, kerugian nilai investasi oleh shareholder dll, seperti yang terjadi pada PT Nissan, Charlos Ghoss memanipulasi laporan keuangan PT Nissan selama lima tahun berturut-turut hingga mengakibatkan kerugian mencapai Rp 641 miliyar (www.Oto.detik.com : 10/03/2019).

Kasus Manipulasi Laporan tersebut mengakibatkan Integritas Laporan Keuangan Perusahaan PT Nissan menurun, sehingga pengguna laporan keuangan tidak mempercayai lagi informasi yang terkandung dalam laporan keuangan tersebut. Kasus manipulasi Laporan keuangan ini menimbulkan pertanyaan tentang Corporate Governance yang berada pada perusaaan tersebut begitupun Auditor eksternal yang mengaudit laporan keuangan tersebut selama lima tahun berturut-turut. Corporate Governance merupakan sistem pengelolaan perusahaan dari hal terkecil hingga hal terbesar (secara luas) (Mudasetia dan Solikhah : 2017). Bagaimana bisa terjadi manipulasi laporan keuangan yang dalam perusahan tersebut terdapat Corporate Governance yang dijalankan sesuai dengan aturannya demi kepentingan bersama. Corporate Governance dapat berupa Kepemilikan Institusional, Kepemilikan Manajerial, Komite Audit, dan Kualitas Audit.

Kepemilikan Institusioanal merupakan banyaknya saham yang dimiliki pihak luar berupa institusi atau badan dengan satuan. Pada Kasus PT Nissan tersebut, yang kemungkinan seharusnya memiliki Kepemilikan Institusinal dapat membantu memonitoring pihak perusahaan dalam mengkritik kebanaran isi yang terkandung pada laporan keuangan PT Nissan, tetapi hal ini tidak terjadi. Menurut penelitian Mais dan Nuari (2016), Kepemilikan oleh lembaga, badan usaha atau institusi sangat penting guana membantu mengawasi kebenaran laporan keuangan perusahaan tempat institusi berinvestasi.

Kepemilikan banyaknya saham yang dimiliki oleh pihak internal perusahaan dalam satuan persen, kememilikan manajerial ini seharusnya dapat menjadi tanggung jawab pihak internal perusahaan untuk selalu bekerja secara jujur dan sesuai aturan (Dewi dan Putra, 2016). PT Nissan kemungkinan memiliki pihak internal yang memiliki beberapa saham PT Nissan seharusnya memiliki sikap tanggung jawab yang tinggi untuk melaporkan Laporan keuangan perusahaan secara jujur dan tidak dimanipulasi, akan tetapi hal ini tidak terjadi pada PT Nissan, dibuktikan dengan adanya manipulasi pada perusahan tersebut selama bertahun-tahun. Menurut Mudasetia dan Solikhah pada (2017) Kepemilikan Manajerial tidak berpengaruh pada Integritas Laporan Keuangan, berlawanan dengan hasil penelitian Dewi dan Putra (2016) yang menghasilkan Kepemilikan Manajerial berpengaruh terhadap Integritas Laporan Keuangan. 
Komisaris Independen merupakan komisaris yang tidak beranggotakan pada organisasi internal perusahaan, komisaris ini berasal dari luar perusahaan yang tidak berhubungan dengan pihak-pihak internal perusahaan, komisaris ini bertugas untuk mempertahankan nama baik perusahaan dan juga mengawasi jalanya pembuatan lapaoran keuangan perusahaan (Dewi dan Putra, 2016). Tetapi pada PT Nissan tidak terlihat adanya Komisaris Independen yang dapat melalukan tugasnya secara baik dan benar, hal ini dibuktikan dengan adanya manipulasi laporan keuangan pada perusahaan tersebut selama lima tahun berturut-turut. Menurut Pratomo dan Nurjannah (2014) mengatakan bahwa Komisaris Independen juga berpengaruh terhadap Integritas Laporan Keuangan, hasil ini berlawanan dengan penelitian Putra dan Dewi (2016).

Komite Audit merupakan komite yang dibentuk untuk membantu tugas dewan komisaris dan bertanggung jawab kepada dewan komisaris, komite ini bertugas mengawasi secara langsung jalanya pembuatan laporan kuangan guna mencegah adanya tindakan manipulasi laporan keuangan (Mudasetia dan Nur Solikhah, 2017). Tetapi pada PT Nissan tidak terlihat adanya Komite Audit yang dapat melalukan tugasnya secara baik dan benar, hal ini dibuktikan dengan adanya manipulasi laporan keuangan pada perusahaan tersebut selama lima tahun berturut-turut. Hasil penelitian yang dilakukan oleh Pratomo dan Nurjannah pada tahun 2014 mengatakan bahwa Komite Audit tidak berpengaruh terhadap Integritas Laporan Keuangan sedangkan penelitian Istiantoro, dkk, (2017) berpendapat sebaliknya.

Selain Corporate Governance yang dijelaskan sebelumnya, Kualitas Audit seoranag auditor independen juga sangat menentukan kebenaran informasi yang terkandung dalam laporan keuangan perusahaan, karena auditor eksternal bertugas mengecek kebenaran informasi tersebut. Qonitin dan Priyandani, 2018). Kualitas Audit ini akan mengungkap hal-hal yang tidak benar adanya pada laporan keuangan perusahaan, hal ini akan mempertahankan Integritas Laporan Keuangan perusahan. Dalam penelitian Nurjannah dan Pratomo (2014) menyatakan bahwa Kualitas Audit berpengaruh terhadap Integritas Laporan Keuangan.

\section{Kajian Teori}

\subsection{Teori Keagenan}

Penelitian ini menggunakan teori keagenan, teori keagenan timbul pada penelitaian ini Karena perbedaan kepentingan yang terjadi pada teorikeagenen akan mempengaruhi Integritas Laporan Keuangan Perusahaan, Pihak agent yang tidak sportif dengan peraturan awal perjanjian dengan prinsipal akan melakukan hal-hal melanggar hukum demi tercapainya kepentingan pribadai ataupun kelompok. Hal-hal tersebut dapat berkaitan dengan memanipulasi laporan keuangan perusahaan untuk meningkatkan feenya dan menekan angka membagian dividen oleh principal, hal ini akan merugikan sebelah pihak dan menguntungkan pihak yang lain dengan cara yang tidak benar.

\subsection{Laporan Keuangan}

Laporan keuangan merupakan Laporan hasil dari informasi-informasi ekonomi perusahaan yang berjalan selama periode akuntansi. Laporan keuangan perusahaan sangat berguna untuk menentukan langkah pihak internal mengambil strategi terbaiknya agar mencapai target tahunan, dan juga berguna untuk pihak investor yang ingin berinvestasi pada perusahaan tersebut.

\subsection{Integritas Laporan Keuangan}

Integritas Laporan Keuangan adalah informasi yang terkandung dalam laporan keuangan kebenaranya dapat di percaya atau laporan keuangan disajikan secara jujur dan benar (Nurjannah, Pratomo : 2014).

$$
\begin{array}{c|c}
\hline \text { INTG }=\frac{\text { Harga Pasar Saham }}{\text { Nilai Buku Saham }} & \text { Keterangan } \\
\text { Sumber : Atiningsih dan Suparwati (2018) } & \text { INTG : Integritas Laporan Keuangan I pada tahun t }
\end{array}
$$




\subsection{Corporate Governance}

Sistem pengelolaan perusahaan dari hal kecil hingga besar (secara keseluruahan) (Mudasetia dan Solikhah, 2017).

1. Kepemilikan Instiusional

Kepemilikan Institusional adalah banyaknya saham yang dimiliki pihak eksternal yang berbadan atau yang berinstitusi.

$$
\text { INS }=\frac{\text { Jumlah saham yang dimiliki oleh institusi }}{\text { Jumlah saham yang beredar }} \times 100 \%
$$

\section{Keterangan}

INS: Kepemilikan Institusional

Sumber : Istiantoro, dkk : 2017

\section{Kepemilikan Manajerial}

Kepemilikan Manajerial banyaknya saham yang dimiliki oleh pihak dalam perusahaan, atau anggota dalam perusahaan (Mudasetia dan Solikhah, 2017).

$$
\text { MNJRL }=\frac{\text { Jumlah saham yang dimiliki oleh manajemen }}{\text { Jumlah saham yang beredar }} \times 100 \%
$$

\section{Keterangan}

Sumber: Istioantoro dkk, 2017

MNJRL : Kepemilikan Manajerial

3. Komisaris Independen

Komisaris Independen merupakan pihak yang berasal dari dewan komisaris yang tidak berhubungan terkait apapun dengan pihak internal perusahaan. (Dewi dan Putra, 2016).

KMSRSIND $=\frac{\text { Jumlah anggota dewan komisaris yang berasal dari luar }}{\text { Total dewan komisaris }} \times 100 \%$

Sumber: Istiantoro, dkk : 2017

\section{Keterangan}

KMSRSIND : Komisaris Independen

4. Komite Audit

Komite Audit merupakan komite yang memeriksa jalanya pembuatan laporan keuangan agar tersaji secara benar dan jujur, komite ini dibentuk oleh dewan komisaris sebagai bentuk untuk membantu dewan komisaris bekerja.

KMTAU $=$ Jumlah Komite Audit yang ada di Perusahaan

Keterangan

KMTAU: Komite Audit

Sumber: Istiantoro, dkk : 2017

5. Kualitas Audit

Kualitas Audit merupakan suatu kecakapan atapun keahlian seorang auditor eksternal dalam memeriksa laporan keuanga perusahaan, kecakapa ini di junjung juga dengan nilai independensi auditor, kompeten auditor dan juga pengalaman auditor dalam menemukan dan mengungkap kesalahan ataupun kecurangan dalam sebuah laporan keuangan perusahaan, dalam penelitian ini Kualitas Audit diklasifikasikan 2 bagian yaitu KAP Big Four dan KAP Non Big Four (Ardiansano dan Nuryanto, 2015):

$1 \quad$ Klynveld Peat Marwick Goerdeler (KMPG) yang berafiliasi dengan KAP Sidharta dan Widjaja.

$2 \quad$ Ernest \& Young (EY) yang berafiliasi dengan KAP Purwantono, Suherman, dan Suraja.

3 PricewaterhouseCoopers (PwC) yang berafiliasi dengan KAP Tanudiredja, Wibisana dan Rekan

4 Deloitte Touche Tohmasu (Deloitte) yang berafiliasi dengan KAP Osman Bing Satrio dan Eny. 
Sumber: Akram, Prayitno, dan Budiarta

\subsection{Kerangka Pemikiran}

Kerangka Pemikiran pada penelitian ini yaitu Coroporate Governance yang diproksi oleh Kepemilikan Institusional, Kepemilikan Manajerial, Komisaris Independen, Komite Audit mempengarusi Integritas Laporan Keuangan, dan Kualitas Audit mempengaruhi Integritas Laporan Keuangan, Kerangka pemikiran penelitian ini dapat digambarkan sebagai berikut:

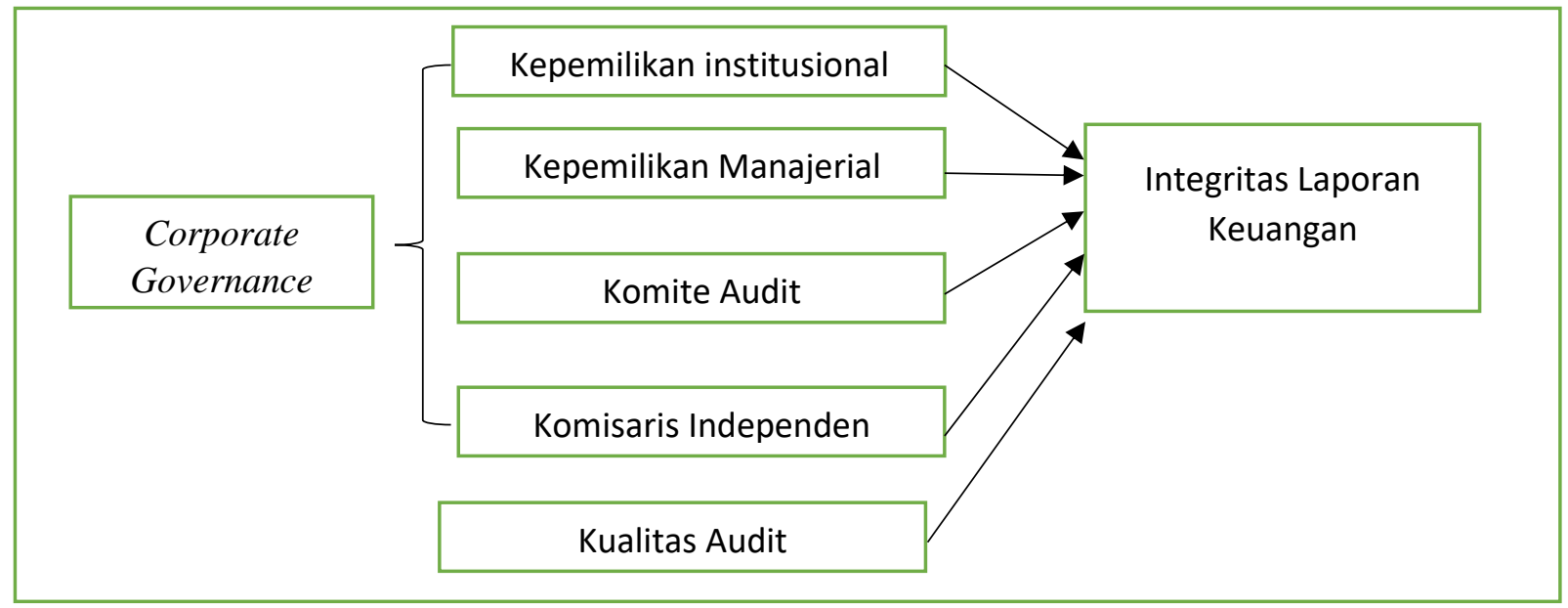

\subsection{Hipotesis}

Gambar 1. Kerangka Pemikiran

1. Pengaruh Kepemilikan Institusional Terhadap Integritas Laporan Keuangan

Nilai presentase Kepemilikan Institusional pada suatu perusahaan berpengaruh terhadap Integritas Laporan keuangan yang diukur dengan Harga pasar perlembar saham dibandingkan dengan nilai buku perlembar saham pada periode tertentu. Semakin tinggi presentase Kepemilikan Institusional, maka semakin tinggi pula nilai Integritas Laporan Keuangan Perusahaan.

H1 : Kepemilikan Institusional Berpengaruh Positif Terhadap Integritas Laporan Keuangan 2. Pengaruh Kepemilikan Manajerial Terhadap Integritas Laporan Keuangan Kepemilikan Manajerial merupakan Kepemilikan oleh pihak internal perusahaan, kepemilikan ini dapat Nilai presentase Kepemilikan Manajerial pada suatu perusahaan berpengaruh terhadap Integritas Laporan keuangan yang diukur dengan Harga pasar perlembar saham dibandingkan dengan nilai buku perlembar saham pada periode tertentu.

H2 : Kepemilikan Manajerial Berpengaruh Positif Terhadap Integritas Laporan Keuangan

3. Komisaris Independen Terhadap Integritas Lapran Keuangan

Nilai presentase Komisaris Independen pada suatu perusahaan berpengaruh terhadap Integritas Laporan keuangan yang diukur dengan Harga pasar perlembar saham dibandingkan dengan nilai buku perlembar saham pada periode tertentu.

H3 : Komisaris Independen Berpengaruh Positif Terhadap Integritas Laporan Keuangan

4. Komite Audit Terhadap Integritas Laporan Keuangan

Komite Audit dikur dari banyaknya jumlah anggota Komite Audit yang berada pada suatu perusahaan, yang mempengaruhi Integritas Laporan keuangan yang diukur dengan Harga pasar perlembar saham dibandingkan dengan nilai buku perlembar saham pada periode tertentu.

H4 : Komite Audit Berpengaruh Positif Terhadap Integritas Laporan Keuangan 
5. Kualitas Audit Terhadap Intergritas Laporan Keuangan

Kaulitas Audit adalah penggunaan KAP Big Four dengan KAP Non Big Four yang mempengaruhi nilai Integritas Laporan keuangan yang diukur dengan Harga pasar perlembar saham dibandingkan dengan nilai buku perlembar saham pada periode tertentu.

H5 : Kualitas Audit Berpengaruh Positif Terhadap Integritas Laporan Keuangan

\section{Metode Penelitian}

Pada penelitian ini menggunakan 13 perusahaan manufaktur sub sektor otomotif dan komponen sebagai populasi yang tercantum di Bursa Efek Indonesia (BEI) periode 2012-2019. Teknik pengujian data pada penelitian ini menggunakan Uji Asumsi Klasik (Uji Normalitas, Uji Multikolinearitas, Uji Hteroskedastisitas, dan Uji Autokolerasi), pada penelitian ini menggunakan Analisis regresi Linier berganda. Teknik pengumpulan sampel menggunakan teknik purposive sampling, dan diperoleh enam perusahaan berikut sebagai sampelnya:

Tabel 1. Sampel Penelitian

\begin{tabular}{|c|c|l|}
\hline No & $\begin{array}{c}\text { Kode } \\
\text { Perusahaan }\end{array}$ & \multicolumn{1}{|c|}{ Nama Perusahaan } \\
\hline 1 & ASII & PT Astra International Tbk \\
\hline 2 & GJTL & PT Gajah Tunggal Tbk \\
\hline 3 & INDS & PT Indospring Tbk \\
\hline 4 & NIPS & PT Nipress Tbk \\
\hline 5 & PRASS & PT Prima Alloy Stel Universal Tbk \\
\hline 6 & SMSM & PT Selamat Sempurna Tbk \\
\hline
\end{tabular}

Model penelitian ini dilakukan dengan analisis regresi linier sederhana. Uji ini dilakukan untuk mengetahui seberapa besar pengaruh variabel independen terhadap satu variabel dependen (Istiantoro, dkk:2017). Hasil dari analisis regresi linear sederhana berupa koefisien untuk variabel independen. Persamaan regresi linear sederhana yang digunakan adalah sebagai berikut:

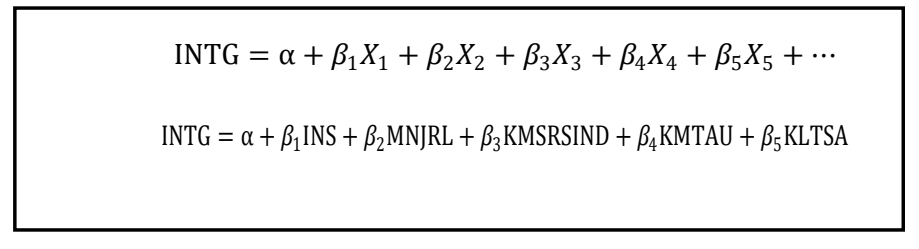

Sumber: Istiantoro, dkk:2017

\section{Keteranqan :}

$\begin{array}{ll}\text { INTG } & : \text { Integritas Laporan Keuangan } \\ \quad \alpha & : \text { Konstanta } \\ \quad \beta_{1}-\beta_{5} & : \text { Koefisien Variabel Independen 1-5 } \\ \quad X_{1}-X_{5} & : \text { Variabel Independen 1-5 } \\ \text { INS } & : \text { Kepemilikan Institusional } \\ \text { MNJRL } & : \text { Kepemilikan Manajerial } \\ \text { KMSRSIND } & : \text { Komisaris Independen } \\ \text { KMTAU } & : \text { Komite Audit } \\ \text { KLTS } & : \text { Kualitas Audit }\end{array}$




\section{Pembahasan}

\subsection{Uji Asumsi Klasik}

4.1.1. Uji Normalitas

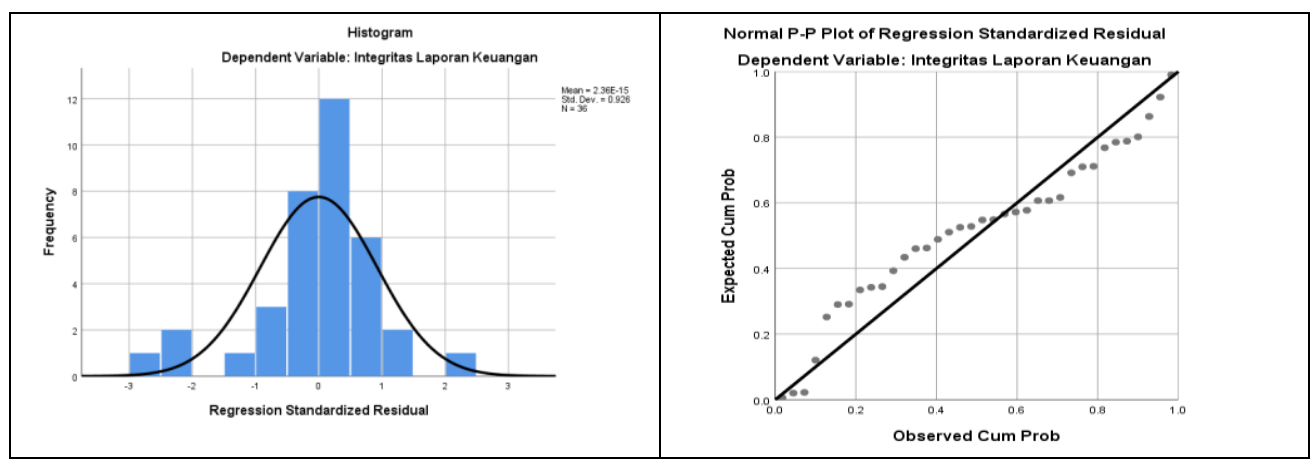

Gambar 2. Hasil Uji Normalitas

Histogram di atas menunjukkan bentuk lonceng ditengah dan tidak menceng kiri ataupun kekanan, yang berarti data terdistribusi normal. Normal Probality Plot di atas menunjukkan titik-titik yang mengikuti garis diagonal, namun agak menjauhi garis, hasil P-plot disamping agak meragukan. Output One Sampel Komlogrov Simrnov di atas menunjukkan bahwa nilai Unstandardized Residual pada Asymp. Sig yang didapat yaitu sebesar 0,090. Sehingga dapat dikatakan bahwa data telah terdistribusi secara normal $(0,090>0,05)$. Hal ini menyatakan bahwa H0 diterima dan H1 ditolak (Normalitas pada Uji One Sampel Kolmogorov Smirnov LOLOS).

\subsubsection{Uji Multikolonieritas}

Tabel 2. Hasil Uji Multikolonieritas

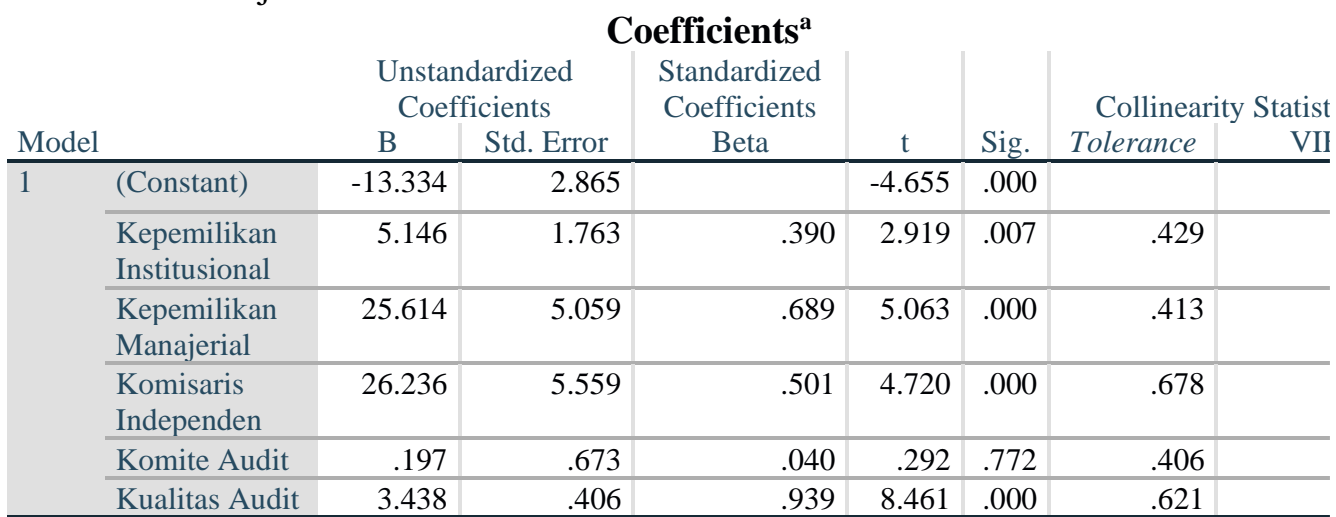

a. Dependent Variable: Integritas Laporan Keuangan

\begin{tabular}{ll} 
Test Statistic & $\ldots \ldots$ \\
Asymp. Sig. (2-tailed) & .136 \\
\hline
\end{tabular}
a. Test distribution is Normal.
b. Calculated from data.
c. Lilliefors Significance Correction.

Output $\mathrm{d}$ atas menunjukkan, diperoleh nilai Tolerance dan VIF dari masing-masing Variabel Independen. Nilai Tolerance seluruh Variabel Independen tidak ada yang dibawah 0.10, begitu pula nilai VIF seluruh Variabel Independen tidak ada nilai yang lebih dari 10, yang berarti Uji Multikolonieritas LOLOS. 
Tabel 3. Scatterplot

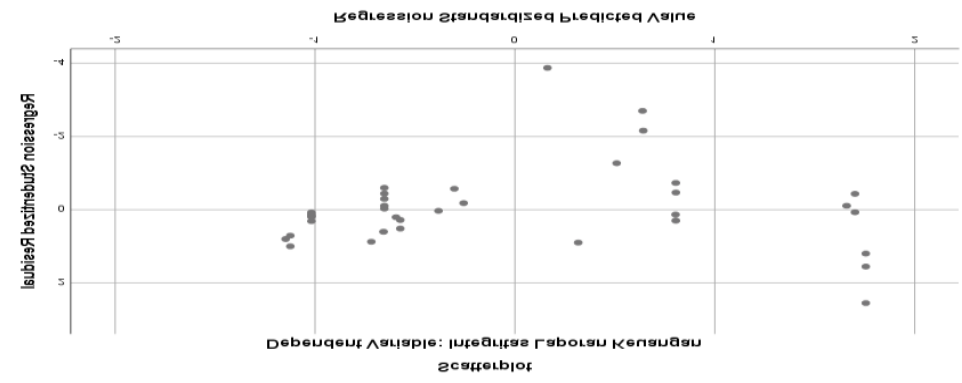

Dari Scatterplot di atas terlihat bahwa titik-titik menyebar tidak membentuk pola tertentu.

\subsubsection{Uji Spearman rho}

Tabel 4. Hasil Uji Spearman rho

\begin{tabular}{|c|c|c|c|c|c|c|c|c|}
\hline & & & Correla & ions & & & & \\
\hline & & & $\begin{array}{c}\text { Unstandar } \\
\text { dized } \\
\text { Residual } \\
\end{array}$ & $\begin{array}{l}\text { Kepemilik } \\
\text { an } \\
\text { Institusion } \\
\text { al }\end{array}$ & $\begin{array}{c}\text { Kepemilik } \\
\text { an } \\
\text { Manajerial } \\
\end{array}$ & $\begin{array}{c}\text { Komisaris } \\
\text { Independe } \\
\mathrm{n}\end{array}$ & $\begin{array}{c}\text { Komite } \\
\text { Audit }\end{array}$ & $\begin{array}{c}\text { Kualitas } \\
\text { Audit } \\
\end{array}$ \\
\hline $\begin{array}{l}\text { Spearman's } \\
\text { rho }\end{array}$ & $\begin{array}{l}\text { Unstandardized } \\
\text { Residual }\end{array}$ & $\begin{array}{l}\text { Correlation } \\
\text { Coefficient }\end{array}$ & 1.000 & -.102 & .253 & -.136 & -.065 & -.003 \\
\hline & & Sig. (2-tailed) & . & .554 & .137 & .429 & .708 & .988 \\
\hline & & $\mathrm{N}$ & 36 & 36 & 36 & 36 & 36 & 36 \\
\hline
\end{tabular}

Dari hasil output diatas menunjukkan bahwa nilai signifikasi dari setiap Variabel Independen tidak ada di bawah 0,005 yang berarti $\mathrm{H} 0$ ditierima yaitu model regresi terjadi Homoskedastisitas atau tidak terjadi Heteroskedastisitas, LOLOS Uji Heteroskedastisitas.

\subsubsection{Uji Autokolerasi}

Tabel 5. Hasil Uji Autokolerasi

\section{Runs Test}

\begin{tabular}{lr} 
& $\begin{array}{c}\text { Unstandardized } \\
\text { Residual }\end{array}$ \\
\hline Test Value & .09116 \\
\hline Cases $<$ Test Value & 18 \\
\hline Cases $>=$ Test Value & 18 \\
\hline Total Cases & 36 \\
\hline Number of Runs & 13 \\
\hline Z & -1.860 \\
\hline Asymp. Sig. (2-tailed) & .063 \\
\hline a. Median
\end{tabular}

Hasil output SPSS menunjukkan nilai test sebesar 0,9116 dengan probabilitas 0,063 signifikan pada 0,005 (Signifikasi (Asymp. Sig ) > 0,05) yang berarti hipotesis H0 diterima, Uji Autokolerasi pada Runtest LOLOS.

\subsection{Analisis Regresi Linier Berganda}

Tabel 6. Hasil Uji Koefisien Determinasi $\left(\mathrm{R}^{2}\right)$

\begin{tabular}{|c|c|c|c|c|c|}
\hline \multicolumn{6}{|c|}{ Model Summary $^{b}$} \\
\hline Model & $\mathrm{R}$ & R Square & Adjusted R Square & $\begin{array}{c}\text { Std. Error of the } \\
\text { Estimate }\end{array}$ & Durbin-Watson \\
\hline 1 & $.878^{\mathrm{a}}$ & .771 & .732 & .95882941 & 1.208 \\
\hline
\end{tabular}


Output SPSS Model Summary besarnya Adjusted $\mathrm{R}^{2}$ adalah 0,732, hal ini berarti 73,2\% Variasi Integritas Lapran Keuangan Perusahaan dapat dijelakan dari lima Variabel Independen yang digunakan dalam penelitian ini. Sedangkan sisanya sebesar 26,8\% (100\%-73,2\%) dijelaskan oleh sebab yang lain di luar model seperti Independensi , Kompensi seorang Auditor, Sikap Kejujuran, teliti, ulet, ketelitian pihak internal perusahaan, dll. Standar Error of the Estimate (SEE) sebesar 0,95882941, nilai SEE yang rendah mengartikan bahwa model regresi tepat dalam memprediksi Variabel Dependen.

Tabel 7. Hasil Uji F

\begin{tabular}{|c|c|c|c|c|c|c|c|c|}
\hline & & & Coeffi & ients $^{a}$ & & & & \\
\hline & & $\begin{array}{r}\text { Unstan } \\
\text { Coeff }\end{array}$ & $\begin{array}{l}\text { rdized } \\
\text { ients }\end{array}$ & $\begin{array}{l}\text { Standardi } \\
\text { zed } \\
\text { Coefficie } \\
\text { nts }\end{array}$ & & & $\begin{array}{r}\text { Collin } \\
\text { Stati }\end{array}$ & $\begin{array}{l}\text { arity } \\
\text { tics }\end{array}$ \\
\hline & & & $\begin{array}{l}\text { Std. } \\
\text { Error }\end{array}$ & Beta & $\mathrm{t}$ & Sig. & $\begin{array}{c}\text { Tolera } \\
\text { nce }\end{array}$ & VIF \\
\hline 1 & (Constant) & -13.334 & 2.865 & & $\begin{array}{r}- \\
4.655\end{array}$ & .000 & & \\
\hline & $\begin{array}{l}\text { Kepemilikan } \\
\text { Institusional }\end{array}$ & 5.146 & 1.763 & .390 & 2.919 & .007 & .429 & 2.332 \\
\hline & $\begin{array}{l}\text { Kepemilikan } \\
\text { Manajerial }\end{array}$ & 25.614 & 5.059 & .689 & 5.063 & .000 & .413 & 2.420 \\
\hline & $\begin{array}{l}\text { Komisaris } \\
\text { Independen }\end{array}$ & 26.236 & 5.559 & .501 & 4.720 & .000 & .678 & 1.476 \\
\hline & Komite Audit & .197 & .673 & .040 & .292 & .772 & .406 & 2.466 \\
\hline & Kualitas Audit & 3.438 & .406 & .939 & 8.461 & .000 & .621 & 1.611 \\
\hline
\end{tabular}

a. Dependent Variable: Integritas Laporan Keuangan

Dari Uji ANOVA atau $\mathrm{F}$ Test didapat nilai $\mathrm{F}_{\text {hitung }}$ sebesar 20,167 sedangkan $\mathrm{F}_{\text {tabel }}$ sebesar 2,53 yang menandakan bahwa $\mathrm{F}_{\text {hitung }}>\mathrm{F}_{\text {tabel }}$ dan signifikansi sebesar $0,000<0,05$ ini menandakan H0 ditolak, atau dengan kata lain Uji model ini layak untuk digunakan pada penelitian.

Tabel 8. Hasil Uji t

\begin{tabular}{|c|c|c|c|c|c|c|c|c|}
\hline & & & Coeffi & ients $^{a}$ & & & & \\
\hline & & $\begin{array}{l}\text { Unstan } \\
\text { Coeff }\end{array}$ & $\begin{array}{l}\text { rdized } \\
\text { ents }\end{array}$ & $\begin{array}{l}\text { Standardi } \\
\text { zed } \\
\text { Coefficie } \\
\text { nts }\end{array}$ & & & $\begin{array}{r}\text { Collir } \\
\text { Stat }\end{array}$ & $\begin{array}{l}\text { arity } \\
\text { ics }\end{array}$ \\
\hline & & & $\begin{array}{l}\text { Std. } \\
\text { Error }\end{array}$ & & $\mathrm{t}$ & Sig. & $\begin{array}{c}\text { Tolera } \\
\text { nce }\end{array}$ & VIF \\
\hline 1 & (Constant) & -13.334 & 2.865 & & -4.655 & .000 & & \\
\hline & $\begin{array}{l}\text { Kepemilikan } \\
\text { Institusional }\end{array}$ & 5.146 & 1.763 & .390 & 2.919 & .007 & .429 & 2.332 \\
\hline & $\begin{array}{l}\text { Kepemilikan } \\
\text { Manajerial }\end{array}$ & 25.614 & 5.059 & .689 & 5.063 & .000 & .413 & 2.420 \\
\hline & $\begin{array}{l}\text { Komisaris } \\
\text { Independen }\end{array}$ & 26.236 & 5.559 & .501 & 4.720 & .000 & .678 & 1.476 \\
\hline & Komite Audit & .197 & .673 & .040 & .292 & .772 & .406 & 2.466 \\
\hline & Kualitas Audit & 3.438 & .406 & .939 & 8.461 & .000 & .621 & 1.611 \\
\hline
\end{tabular}

a. Dependent Variable: Integritas Laporan Keuangan

Output Uji t di atas menunjukan Kepemilikan Institusional, Kepemilikan Manajerial, Komisaris Independen, dan Kualitas Audit berpengaruh terhadap Integrtas Laporan Keuangan karena memiliki nilai signifikansi dibawah 0,005, sedangkan Komite Audit teidak berpengaruh terhadap Integritas Laporan Keuangan, karena signifikansinya diatas 0,005 .

\subsection{Interpretasi Hasil Penelitian}

1. Pengaruh Kepemilikan Institusional Terhadap Integritas Laporan Keuangan

Hasil penelitian menghasilkan bahwa Variabel Kepemilikan Institusional berpengaruh terhadap Integritas Laporan Keuangan atau dengan kata lain $\mathrm{H} 1$ diterima, dengan arah koefisien positif artinya 2021 | Studi Akuntansi, Keuangan dan Manajemen (Sakman)/ Vol 1 No 1, 33-43 
semakin banyak jumlah Kepemilikan Institusional maka semakin baik Integritas Laporan Keuangan Perusahaan. Hasil ini sejalan dengan teori yang telah disebutkan di bab sebelumnya bahwa Kepemilikan saham yang dimiliki oleh institusi/lembaga/badan usaha akan menjadi pihak ketiga yang mengawasi kebenaran informasi pada laporan keuangan perusahaan tempat institusi tersebut berinvestasi. Hasil penelitian ini konsisten dengan hasil penelitian Dewi dan Putra (2016), Atiningsih dan Suparwsti (2018) yang menyatakan bahwa Kepemilikan Institusional berpengaruh terhadap Integritas Laporan Keuangan.

\section{Pengaruh Kepemilikan Manajerial Terhadap Integritas Laporan Keuangan}

Hasil penelitian menghasilkan bahwa Kepemilikan Manajerial berpengaruh terhadap Integritas Laporan Keuangan, hal ini berarti $\mathrm{H} 2$ diterima dengan arah koefisien positif yang berarti bahwa semakin banyak jumlah Kepemilikan Manajerial maka semakin baik Integritas Laporan Keuangan Perusahaan. Hasil ini sejalan dengan teori bab sebelumnya dikatakan bahwa pihak manajer dalam perusahaan yang memiliki presentase Kepemilikan Manajerial akan cenderung berhati-hati dalam bertindak dikarenakan pihak internal atau manajerial tersebut juga ikut dalam permodalan perusahaan. Hasil penelitian ini konsisten dengan hasil penelitian Hardiningsih (2010), Dewi dan Putra (2016), dan Atiningsih dan Suparwati (2018) yang menyatakan Kepemilikan Institusional berpengaruh terhadap Integritas Laporan Keuangan.

\section{Pengaruh Komisaris Independen Terhadap Integritas Laporan Keuangan}

Hasil penelitian menghasilkan bahwa Komisaris Independen berpengaruh terhadap Integritas Laporan Keuangan yang berarti $\mathrm{H} 3$ diterima, dengan arah positif yang berarti semakin banyak jumlah Komisaris Independen maka semakin baik Integritas Laporan Keuangan Perusahaan. Hasil ini sejalan dengan teori yang telah disebutkan sebelumnya bahwa Komisaris Independen berfungsi untuk menyeimbangkan dalam pengambilan keputusan terutama dalam mengawasi keamanan hak-hak shareholder dll. Hasil penelitian ini konsisten dengan hasil penelitian Mais Dan Nuari (2016), Dewi dan Putra (2016) yang menyatakan bahwa Komisaris Independen berpengaruh terhadap Integritas Laporan Keuangan.

\section{Pengaruh Komite Audit Terhadap Integritas Laporan Keuangan}

Hasil penelitian menunjukkan bahwa Komite Audit tidak berpengaruh terhadap Integritas Laporan Keuangan, yang berarti H4 ditolak, tetapi Komite Audit memiliki koefisien dengan arah positif yang berarti semakin banyak jumlah Komite Audit maka semakin baik Integritas Laporan Keuangan Perusahaan. Hasil ini tidak sejalan dengan teori yang telah disebutkan karena, Komite Audit diangkat dan bertanggung jawab oleh Komisaris Independen, sehingga keberadaannya hanya membantu menyelesaikan dan mengefektifkan tugas Komisaris Independen, namun keberadaannya tidak dapat memutuskan sesuatu hal yang berkaitan dengan Integritas Laporan Keuangan, hal ini menyebabkan jumlah Komite Audit tidak berpengaruh terhadap Integritas Laporan Keuangan. Hasil penelitian ini konsisten dengan hasil penelitian Mudasetia dan Solikhah (2017), Wulandari dan Budiarta (2014), dan Atiningsih dan Suparwati (2018) yang menyatakan bahwa Komite Audit tidak berpengaruh terhadap Integritas Laporan Keuangan.

\section{Pengaruh Kualitas Audit Terhadap Integritas Laporan Keuangan}

Hasil penelitian menunjukkan bahwa Kualitas Audit berpengaruh terhadap Integritas Laporan Keuangan yang berarti H5 diterima, dengan arah positif yang berarti semakin berkualitas Kualitas Audit maka semakin baik Integritas Laporan Keuangan Perusahaan. Hasil ini sejalan dengan teori yang telah disebutkan pada bab sebelumnya yang mengatakan bahwa semakin baik Kualitas Audit suatu KAP maka auditor di suatu perusahaan akan mengungkap dan memberikan opini seadanya berdasarkan laporan keuangan yang telah diaudit, oleh sebab itu Kualitas Audit akan membuat laporan keuangan perusahaan semakin dipercaya oleh pihak eksternal yang menandakan Integritas Laporan Keuangan akan meningkat atau terjaga. Hasil penelitian ini konsisten hasil Nurjannah dan Pratomo (2014), Mudasetia dan Solikhah (2017) dan Qonitin, dkk (2018) yang menyatakan bahwa Kualitas Audit berpengaruh terhadap Integritas Laporan Keuangan Perusahaan. 


\section{Kesimpulan}

Kepemilikan Institusional, Kepemilikan Manajerial, Komisaris Independen, Kualitas Audit berpengaruh positif dan signifikan terhadap Integritas Laporan Keuangan pada Perusahaan Manufaktur Sub Sektor Otomotif dan Komponen yang tercantum di BEI periode 2012-2017, sedangkan Komite Audit tidak berpengaruh terhadap Integritas Laporan Keuangan pada Perusahaan Manufaktur Sub Sektor Otomotif dan Komponen yang tercantum di BEI periode 2012-2017. Setelah diketahui hasil penelitian diatas, diharapkan kepada investor pada suatu perusahaan selalu memperhatikan hal-hal yang mempengaruhi Integritas Laporan Keuangan guna memberikan ketengangan dalam berinvestasi, dan kepada perusahaan agar selalu mempertahankan Integrirtas Laporan Keuangan perusahaan agar selalu mendapatkan kepercayaan dari seluruh pihak terutama pihak investor.

Untuk perusahaan sebagai informasi kepada pihak manajemen perusahaan bahwasannya jumlah Kepemilikan Manajerial berpengaruh terhadap Integritas Laporan Keuangan perusahaan , diharapkan hal ini dapat menjadi motivasi pihak manajemen perusahaan untuk selalu bersikap jujur dan bertanggung jawab untuk kepentingan bersama, menerapkan sistem yang benar-benar transparan agar seluruh pihak yakin dengan informasi-informasi yang tercermin dalam laporan keuangan benar adanya sehingga Integritas Laporan Keuangan terjaga dengan baik.

\section{Referensi}

Atiningsih, Suci dan Yohana, Kus Suparwati. (2018). Pengaruh Corporate Governance dan Leverage Terhadap Integritas Laporan Keuangan. Jurnal Ilmu Manajemen dan Akuntansi : Vol 9 No 2.

Bursa Efek Indonesia. 2019. setiap tahunnya menerbitkan laporan keuangan tahunan yang sudah diaudit. www.idx.com. Diakses pada tanggal 10 Maret 2019.

Finance, Detik. 2015. Badan Pusat Statistik (BPS) telah melakukan sensus ekonomi 2016. https://finance.detik.com. Diakses pada tanggal 10 April 2019.

Firdaus dan Fakhry, Zamzam. (2018). Aplikasi Metodelogi Penelitian. Yogyakarta : 2018.

Ikatan Akuntan Indonesia. (2018). Standar Akuntansi Indonesia. Jakarta : IAI.

Istiantoro,Inosensius, Ardi Paminto dan Herry Ramadhan. (2017). Pengaruh Struktur Corporate Governance terhadap Integritas Laporan Keuangan pada Perusahaan LQ45 yang terdaftar di BEI. E-Journal Vol.14 No.2:157-179.

Mais, Rimi Gusliana dan Fadlan Nuari. (2016). Pengaruh Good Corporate Governance, Ukuran Perusahaan dan Leverage terhadap Integritas Laporan Keuangan. Jurnal Reviu Akuntansi dan Keuangan Vol. 6 No.2:907-912.

Pasal 25 nomor 1,2 dan 3 pada Peraturan Otoritas Jasa Keuangan Nomor 33/POJK.04/2014

Peraturan Otoritas Jasa Keuangan Nomor 33/POJK.04/2014 Pasal 1 nomor 4 tentang Direksi dan Dewan Komisaris emiten atau perusahaan Publik

Peraturan Otoritas Jasa Keuangan Nomor 33/POJK.04/2014 Pasal 20 nomor 3 tentang Direksi dan Dewan Komisaris emiten atau perusahaan Publik

Saham, Ok. 2016. Jumlah perusahaan yang sudah go public yang tercantum di Bursa Efek Indonesia. Diakses pada tanggal 10 April 2019.

Subramayam K.R. (2017). Analisis Laporan Keuangan (Financial Statement Analysis). Jakarta : Salemba Empat.

Wahyudiono, Bambang. (2014). Mudah Membaca Laporan Keuangan. Jawa Timur : Raih Asa Sukses. 